Article

\title{
Cross-Linguistic Transfer of Object Clitic Structure: A Case of L3 Brazilian Portuguese
}

\author{
Alan Parma \\ Department of Modern Languages and Linguistics, 625 University Way, PO Box 3061540, \\ Florida State University, Tallahassee, FL, 32306, USA; afp11b@my.fsu.edu; Tel.: +1-850-644-5349 \\ Academic Editors: Maria del Carmen Parafita Couto and Usha Lakshmanan \\ Received: 22 June 2017; Accepted: 7 August 2017; Published: 14 August 2017
}

\begin{abstract}
This study examines the role of previously known language in L3 Brazilian Portuguese (BP) object expression acquisition. It investigates the claims of the main models of L3 transfer, the cumulative enhancement model (CEM) (Flynn et al. 2004), the L2 status factor (Bardel and Falk 2007) and the typological proximity model (TPM) (Rothman 2011) in both comprehension and production tasks. It also aims at measuring the extent of transfer effects in comprehension and production. Participants $(N=33)$ were divided into three groups, a mirror image group of L3 BP learners who already knew English and Spanish, and a native control group. They performed a self-paced reading task and a story telling task, which focused on object clitics in BP. Results indicate early convergence to the $\mathrm{BP}$ grammar by the L3 learners in what refers to object expression. They also suggest that, although no major effects of transfer were obtained, clitic placement errors in the production task and preference for inanimate and non-specific contexts for null objects can be traced to Spanish, independent of order of acquisition, providing evidence in favor of the TPM. Finally, comprehension seems to override the effects of language transfer earlier than production.
\end{abstract}

Keywords: L3 acquisition; language transfer; object clitics; Brazilian Portuguese

\section{Introduction}

In the past, research on third language (L3) acquisition was conducted under the scope of second language (L2) acquisition, based on the assumption that the process of acquiring a further non-native language is the same as acquiring the first one [1]. However, recent research in the field has shown that L3 acquisition should be a subfield of its own [2], since the previously known languages can impact on the acquisition process of a third one. The fact of having acquired an L2, concerning the process of learning and the product of that learning experience, can potentially influence the acquisition of an L3, and this involves a quality change in language learning and processing [2-5]. One of the most investigated questions in the L3 acquisition field has been the roles played by the previously known languages in L3 interlanguage development [6].

Researchers have sought to identify the potential source of transfer in L3 acquisition initial states, as well as the interplay between the known languages in the learners' brain. The most influential proposals differ on the predicted source of transfer. Flynn et al. claim that all languages previously known by the learner can potentially (positively) influence the development of subsequent language learning [7]. Barden and Falk [8], on the other hand, propose that the L2 blocks access to the L1 and acts as the only source for transfer in L3 acquisition. Finally, Rothman claims language transfer depends on how structurally related the three languages are, and language transfer occurs based on typology [6].

All the above proposals for morphosyntactic transfer have been empirically investigated, mainly in off-line and production measures [6-11]. Montrul et al. tested the predictions of these models for language transfer in the L3 acquisition of object clitics in Brazilian Portuguese (BP) by English and 
Spanish bilinguals [12]. They conducted a grammaticality judgment task as well as an oral production task and found evidence of transfer from Spanish, the most typologically similar language to BP. They claim, thus, that structural similarity is the main reason for L3 transfer to occur. It remains to be seen whether transfer is also observed in on-line comprehension measures and which model better accounts for the data obtained.

My goal in this paper is to fill this gap in the field by investigating cross-linguistic transfer in the acquisition of object clitics in L3 BP in both comprehension and production data. By the means of an experimental design that allows the examination of the models for morphosyntactic transfer above mentioned, this paper intends to identify the one that better accounts for the data obtained, as well as to discuss the effects of transfer in the two types of data analyzed. This paper is structured as follows. In Section 2, I begin by describing the morphosyntactic transfer models under investigation and their predictions. Section 3 provides the syntactic contrast among BP, Spanish and English in terms of clitic object expression. Section 4 presents the methodology of this study, followed by its results. I discuss the results in Section 5, as well as the limitations of the study and directions for future investigations. Finally, I provide the concluding remarks in Section 6.

\section{Models of Morphosyntactic Transfer in L3 Acquisition}

\subsection{The Cumulative-Enhancement Model}

In their pioneering study on morphosyntactic multilingual transfer, Flynn et al. propose that any previously known language is equally important and equally available for playing some role in L3 acquisition [7]. According to the authors, language learning is cumulative and excludes redundancy in linguistic representation, i.e., the accumulated linguistic knowledge necessarily enhances subsequent language learning. This model is called the cumulative-enhancement model (CEM). Crucial to their proposal, language transfer is either facilitative, that is, it positively assists subsequent language acquisition, or it remains neutral.

They based their assumptions on Flynn's studies of Japanese and Spanish L1 speakers acquiring relative clauses in L2 English $[13,14]$. Japanese is a head-final language with left-branching relative clauses, and, therefore, does not match English or Spanish in head direction (head-initial, right branching). The results of these studies suggested that acquisition of relative clauses in L2 English differs between the L1 Spanish and the L1 Japanese group. The author claims that, since the Japanese speakers were in contact with a right-head relative clause for the first time when they were acquiring their L2, they had to establish this parametric value to English from a scratch. Spanish speakers, however, had already had contact with a language-specific grammar realized as head-initial, right-branching, thus this parametric value did not have to be re-established for another language-specific grammar, once it was already somehow represented in their minds/brains. Flynn et al. experimented the same concept, in an elicited imitation task, with L1 Kazakh/L2 Russian learners of L3 English [7]. The L3 English matches with the L2 Russian, but not with the L1 Kazakh in word order and head direction. As a consequence, "if the L3 learner is to draw on experience with a right-branching language in constructing relative clauses in English, this experience would have to come from Russian, and not from Kazakh" [7] (p. 10).

The authors found similar patterns to those for L1 Spanish acquisition of L2 English, that is, transfer was found to originate from L2 Russian, a language similar to L3 English in head-direction, and to have a facilitative effect on L3 acquisition. They claim these results suggest that prior complementizer phrase (CP) development can influence development of $\mathrm{CP}$ structure in subsequent language acquisition, and that experience in any prior language can be drawn upon in subsequent acquisition.

\subsection{The L2 Status Factor}

The L2 status factor claims that the L2 acts as a filter to block L1 syntactic transfer, leaving the L2 as the exclusive source of transfer in L3 acquisition $[8,10,15]$. According to the authors, this happens because L2 and L3 are more cognitive similar than L1 and L3: the learner classifies L1 as native, which differs 
from the classification of L2 and L3 as non-natives. Adopting Paradis's distinction between declarative and procedural memory systems [16], the authors argue that the native language (L1) is sustained by procedural memory, which involves implicit linguistic competence. All late-learned languages (L2, L3, Ln), at least at initial stages of acquisition, are sustained by declarative memory, which entails conscious representations of language. As a result, the L2 is more likely to transfer to the L3.

The authors tested their hypothesis in a study on negation placement examining two different groups [8]: L1 V2/L2 non-V2 and L1 non-V2/L2 V2 (where V2 refers to a language whose finite verb is obligatorily the second constituent in the main clauses or in all the finite clauses), beginning learners of Dutch or Swedish as an L3, both V2 languages. Their results showed that the L2 V2 group had no problems in placing negation post-verbally, resulting in target-like instances. Meanwhile, the L2 non-V2 group placed the negation pre-verbally in most of the cases, resulting in ungrammaticality in the target L3. Bardel and Falk attributed the differences in negation placement between the groups to transfer from their respective L2s, in support of the L2 status factor [8]. Also, their results are claimed to be evidence against the CEM, since negative transfer from the L2 non-V2 group occurred, instead of being just neutral, and L1 V2 did not seem to be relevant to L3 production.

\subsection{The Typological Proximity Model}

Finally, the typological proximity model (TPM) $[6,17]$ differs from the L2 status factor, in that any language can be the source of transfer, and also distances itself from the CEM by claiming that language transfer will be either facilitative or negative. According to the TPM, language acquisition is a cumulative and selective process, and operates under principles of universal economy. This economy does not solely refer to the universal restriction of grammatical formation of individual grammars, but also to "a larger sense of general cognitive economy that employs prior knowledge to streamline subsequent processes" [6] (p. 123). The concept of cognitive economy as seen by the TPM is defined as the mind's predisposition to put forth the least amount of effort towards a cognitive task [17]. Such predisposition manifests itself in transfer patterns with the purpose of reducing processing costs at different levels, following a similar logic to the one for full L1 transfer in L2 acquisition $[18,19]$. The model assumes the actual or perceived structural similarity $[20,21]$ between the previously known languages and the L3 constraints the language parser and the syntactic properties of the closest (psycho)typological language constitute the initial state of L3 acquisition [6].

Empirical evidence for the TPM comes from the comparison of two groups [6], an L1 Italian/L2 English at the low to intermediate proficiency level of L3 Spanish, and an L1 English/L2 Spanish also at low to intermediate level of L3 BP. Participants performed a semantic interpretation task and a collocation task aimed at investigating the nuances in meaning of adjectival placement. Both groups performed similarly and within the range of the native control individual performances. The predictions of the TPM were borne out, that is, transfer was obtained from the previously known Romance language, and not from English, irrespective of order of acquisition or the status as an L2.

\section{Object Clitics in Spanish and BP}

Soriano defines clitics as unstressed object pronominal forms that appear united to the verb [22]. Both Spanish and BP present clitics, whereas English lacks these structures. Instead, English uses object pronouns, as it can be seen in the contrast below:

1. a. I called you last night. English

b. Te llamé anoche. Spanish

c. Eu te telefonei na noite passada. BP

In (1a), the complement of the verb called is expressed by a strong pronoun, you. In examples $(1 \mathrm{~b}, \mathrm{c})$, both Spanish and BP express such complement by the second person accusative clitic te 'you.' 
Although Spanish and BP present several similarities, the syntax of these languages also displays a considerable amount of differences in what refers to the constructions with object clitics. The main similarities and differences of relevance to the purposes of this study are summarized below.

First, I discuss the position of clitics in BP and Spanish. There are two possible positions for the clitic: post-verbally, also known as enclisis, and pre-verbally, or proclisis. Galves et al. [23] demonstrate how BP favors the proclisis position, even in contexts in which European Portuguese (EP) would require enclisis, such as in absolute V1 contexts. The authors consider this an innovation of BP syntax. Enclisis is a possibility in BP, although it has become less and less frequent. The difference here is allegedly due to register: informal and oral contexts use proclisis exclusively, while formal (written) register would favor enclisis and proclisis would be a more constrained construction, limited to some contexts shown below. However, it is important to mention the claim that enclisis is not considered to be part of the BP grammar any longer, and such a construction still persists in the language due to formal schooling $[23,24]$. Following prescriptive rules, the ones explicitly taught at schools, enclisis is the preferred pattern for clitic placement in the written register, but proclisis is obligatory in BP when the clitic follows a negative word (2) or a conjunction (3). Enclisis, on the other hand, is obligatory in absolute V1 contexts (4), as shown in the examples below.

\begin{tabular}{|c|c|c|c|c|c|c|c|c|}
\hline 2. a. & $\begin{array}{l}\text { Minha } \\
\text { My }\end{array}$ & $\begin{array}{l}\text { irmã } \\
\text { sister }\end{array}$ & $\begin{array}{l}\text { não } \\
\text { no }\end{array}$ & $\begin{array}{l}\text { me } \\
\text { CL1sg }\end{array}$ & $\begin{array}{l}\text { telefonou } \\
\text { called }\end{array}$ & $\begin{array}{l}\text { no } \\
\text { in }\end{array}$ & $\begin{array}{l}\text { meu } \\
\text { my }\end{array}$ & $\begin{array}{l}\text { aniversário. } \\
\text { birthday }\end{array}$ \\
\hline b. & $\begin{array}{l}{ }^{*} \text { Minha } \\
\text { My }\end{array}$ & $\begin{array}{l}\text { irmã } \\
\text { sister }\end{array}$ & $\begin{array}{l}\text { não } \\
\text { no }\end{array}$ & $\begin{array}{l}\text { telefonc } \\
\text { called-C }\end{array}$ & & $\begin{array}{l}\text { no } \\
\text { in }\end{array}$ & $\begin{array}{l}\text { meu } \\
\text { my }\end{array}$ & $\begin{array}{l}\text { aniversário. } \\
\text { birthday }\end{array}$ \\
\hline
\end{tabular}

\begin{tabular}{|c|c|c|c|c|c|c|c|}
\hline a. & $\begin{array}{l}\text { Eu } \\
\text { I }\end{array}$ & $\begin{array}{l}\text { fiquei } \\
\text { got }\end{array}$ & $\begin{array}{l}\text { feliz } \\
\text { happy }\end{array}$ & $\begin{array}{l}\text { quando } \\
\text { when }\end{array}$ & $\begin{array}{l}\text { te } \\
\text { CL2sg }\end{array}$ & $\begin{array}{l}\text { vi } \\
\text { saw }\end{array}$ & $\begin{array}{l}\text { na } \\
\text { in }\end{array}$ \\
\hline b. & $\begin{array}{l}{ }^{*} \mathrm{Eu} \\
\mathrm{I}\end{array}$ & $\begin{array}{l}\text { fiquei } \\
\text { got }\end{array}$ & $\begin{array}{l}\text { feliz } \\
\text { happy }\end{array}$ & $\begin{array}{l}\text { quando } \\
\text { when }\end{array}$ & $\begin{array}{l}\text { vi-te } \\
\text { saw-CL2sg }\end{array}$ & & $\begin{array}{l}\text { na } \\
\text { in }\end{array}$ \\
\hline
\end{tabular}

4. a. $\begin{array}{lll}\text { *Te mandei } & \text { um } & \text { e-mail. } \\ \text { CL2sg sent } & \text { a } & \text { e-mail }\end{array}$
b. $\begin{array}{lll}\text { Mandei-te } & \text { um } \\ & \begin{array}{l}\text { sent-CL2sg } \\ \text { 'I sent you an e-mail' }\end{array}\end{array}$

Example (4) requires attention. Although prescriptive rules determine that clitics are placed post-verbally in absolute V1 contexts, ruling (4b) as the expected construction, (4a) is widely accepted by BP native speakers, even in formal registers. This could result in a conflict for BP non-native speakers, who would find evidence of constructions such as (4a) in the input they are exposed to, but, at the same time, would be confronted with the rules of the standard variety of BP, which prescribes (4b) as the only accepted construction. In order to avoid this kind of contrasting evidence, this study makes use of constructions such as (2), in which proclisis is mandatory. By doing so, it makes use of the clitic position which is more frequent in the input to which these learners are exposed, i.e., proclisis.

Placement in Spanish is determined by finiteness, and not by the morpho-phonological context in which the clitic occurs. According to Soriano [22], clitics appear proclitic to the verb if the latter is finite (5), but enclitic to it if the verb is non-finite (6) or gerund (7). See the contrast below, in which BP allows (and favors) proclisis in all of these conditions. 
Spanish

5. a. Juan

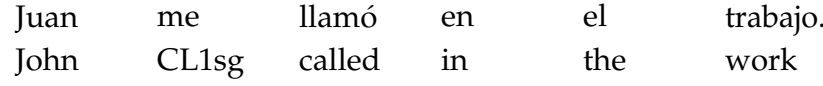

$\begin{array}{llll}\text { b. 'Juan llamóme } & \text { en } & \text { el } & \text { trabajo. } \\ \text { John called-CL1sg } & \text { in } & \text { the } & \text { work } \\ \text { 'John called me at work' } & & & \end{array}$

6. a. No es bueno admirarme tanto.

no is good to-admire-CL1sg this-much
b. *No es bueno me admirar tanto.
no is good CL1sg to-admire this-much

'It is not good to admire me this much'

7. a. Está esperándome.

is waiting-CL1sg

b. *Está me esperando.

is CL1sg waiting

'He/She is waiting for me'

$B P$

8. a. João me telefonou no trabalho.

John CL1sg called in-the work

b. ?João telefonou-me no trabalho.

John called-CL1sg in-the work

'John called me at work'

9. a. Não é bom me admirar tanto.

no is good CL1sg to-admire this-much

b. ?Não é bom admirar-me tanto.

No is good to-admire-CL1sg this-much

'It is not good to admire this much'

10. a. Ele está me esperando.

$\mathrm{He}$ is CL1sg waiting

b. ?Ele está esperando-me.

$\mathrm{He}$ is waiting-CL1sg

'He is waiting for me'

As seen above, Spanish determines appropriate clitic placement according to the verbal inflection: finite verbs require proclisis, whereas infinitives and gerunds, enclisis. BP, on the other hand, favors proclisis in every condition, independent of verbal inflection. The question mark in the enclisis conditions indicate that, although possible, this construction has a very marginal use in the actual grammar of native speakers, mostly limited to written mode.

Another difference related to placement refers to restructuring constructions, i.e., sequences of finite and non-finite verbs, in which the former could be a modal, an auxiliary, a perception or a causative verb [12]. In Spanish, there are two possible positions for the clitic: pre-verbally to the auxiliary or 
finite verb, a construction called clitic climbing, or post-verbally to the non-finite verb, also known as non-climbing. The middle position is strictly ungrammatical in Spanish. In BP, although non-climbing is somewhat accepted, the preferred position for the clitic is the middle position, between the auxiliary and the non-finite verb. Clitic climbing is completely unacceptable in BP $[25,26]$.

\section{Spanish}

11. a. $\mathrm{Te}$

Te
CL2sg

$$
\begin{array}{ll}
\text { voy a } & \text { am-going to }
\end{array}
$$

contar una

cosa.

b. *Voy a

am-going to

te

tell

a

thing

c. Voy

CL2sg

contar

una

cosa.

tell a

thing

am-going to

contarte

tell-CL2sg

una

cosa.

'I am going to tell you something'

a thing

BP

12. a. ${ }^{*} \mathrm{Eu}$ te

I CL2sg

$$
\begin{aligned}
& \text { vou } \\
& \text { am-going }
\end{aligned}
$$

contar uma

coisa.

b. Eu vou

te

to-tell

a

thing

I am-going

CL2sg

contar uma

coisa.

c. ?Eu vou

contar-te

to-tell a

thing

I am-going to-tell-CL2sg

uma coisa.

'I am going to tell you something'

Also, BP allows 3rd person strong pronouns as the internal argument of the verb, whereas Spanish requires a clitic. The occurrence of 3rd person strong pronouns in BP is related to the loss of its 3rd person accusative clitics and the emergence of null object constructions [25], which will be discussed shortly.

Spanish

13. a. La

$\begin{array}{ll}\text { La } & \text { conozco } \\ \text { CL3sg } & \text { know }\end{array}$

b. $\quad{ }^{*}$ Conozco ella.

know her

'I know her'

$B P$

14. a. Eu a conheço.

b. Eu conheço ela.

I know her

'I know her'

Finally, a last difference between BP and Spanish refers to the occurrence of null objects. BP has almost completely lost its 3rd person accusative clitics, $o(s) / a(s)$ 'him/her/them' (see [25-29] among others). Silveira says the 3rd person accusative clitics are in complementary competition with constructions presenting strong pronouns, as well as null object constructions [30]. They are also in competition with full Noun Phrases (NPs), as seen in the examples below. 


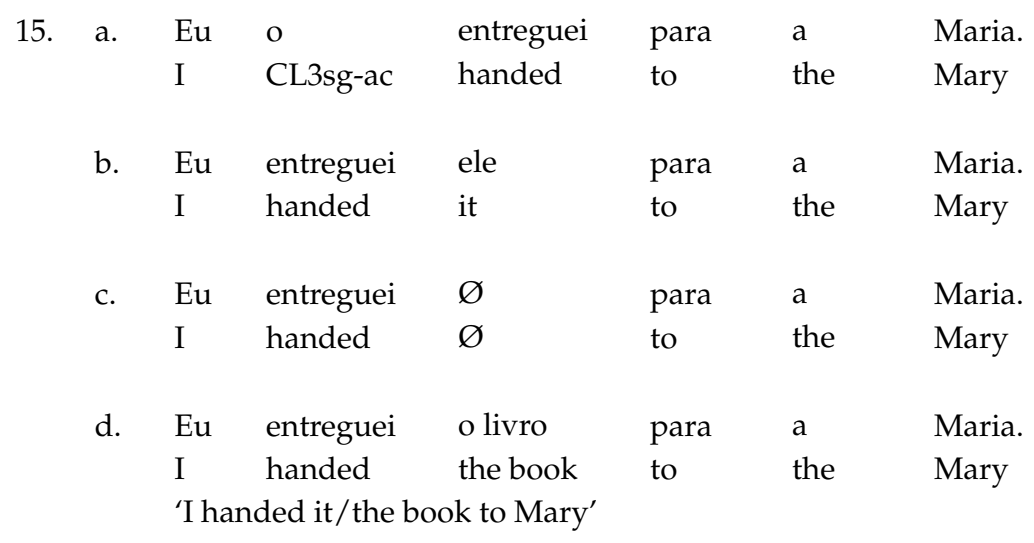

Example (15a) is the dispreferred form in current BP, since the 3rd person accusative clitics have become obsolete forms $[23,30]$. These clitics are formal and are not possible in some registers. In fact, the 3rd person accusative clitics seem to be limited to formal written registers. Instead, BP uses strong pronouns, null object constructions and full NPs in object positions, as respectively shown by (15b-d). Galves et al. [23], contrasting the BP version of the book The Alchemist, by Paulo Coelho, with its EP adaptation [31,32], demonstrate that, in the former, there is a strong tendency to avoid the 3rd person accusative clitic, replacing it by the other forms shown in the examples above. They claim that the clitics $o / a$, when used, are reminiscent of old grammars, and are acquired later [33]. They also state that these forms are acquired just formally, at school, and do not belong to the grammar of the language anymore. It is important to note that the null object constructions are limited to 3rd person reference (therefore they only compete with 3rd person accusative clitics), and cannot be extended to any other person or case in the clitic paradigm [34].

Although Spanish also allows null object constructions, the contexts in which they occur are much more restricted. Null objects are grammatical in Spanish when they refer to inanimate and non-specific objects, as observed in (16). On the other hand, when they refer to animate and specific objects, they are ungrammatical, as seen in (16b), and a clitic is required. ${ }^{1}$ Contrast it with the BP counterparts in (17).

Spanish

$\begin{array}{rllllllll}\text { 16. a. Pedro fue a comprar } & \text { vino } & \text { pero no } & \varnothing & \text { encontró. } \\ & \text { Peter went to buy } & \text { wine but } & \text { not } & \varnothing & \text { found }\end{array}$

'Peter went to buy wine but did not find any'

$\begin{array}{cllllllll}\text { b. } & \text { *Pedro fue a buscar a } & \text { María pero no } & \varnothing & \text { encontró. } \\ \text { Peter went to look } & \text { for } & \text { Mary but } & \text { not } \varnothing & \text { found }\end{array}$

$B P$

$\begin{array}{lllllllll}\text { 17. a. } \mathrm{O} & \text { Pedro foi } & \text { comprar } & \text { vinho, mas } & \text { não } & \varnothing & \text { achou. } \\ \text { the } & \text { Peter } & \text { went to-buy } & \text { wine } & \text { but } & \text { not } & \varnothing & \text { found }\end{array}$

'Peter went to buy wine but did not find any'

$\begin{array}{llllllllll}\text { b. O } & \text { Pedro foi } & \text { buscar } & \text { a } & \text { Maria, mas não } & \varnothing & \text { achou. } \\ \text { the } & \text { Peter went to-look-for the } & \text { Mary but not } \varnothing & \text { found. }\end{array}$

'Peter went to look for Mary but did not find her'

There are other differences between BP and Spanish in what refers to object expression, such as the presence in the latter of the differential object marker (DOM) $a$, as well as the occurrence of clitic

1 I refer the reader to Rizzi [35] for a more complete analysis of null objects in Italian, but whose analysis can also be extended to Spanish, as suggested by an anonymous reviewer. 
doubling and double object constructions in Spanish. Given that these structures are not relevant to the present study, I will not discuss them here. I refer the reader to Montrul et al. for an extensive discussion on these phenomena [12].

In sum, despite some similarities in clitic object expression, Spanish and BP differ in the following manner: (1) BP favors proclisis, even when the verb is non-finite or a gerund; (2) in restructuring constructions, BP favors the middle position, whereas Spanish allows clitic climbing and non-climbing to occur, but the middle position is ungrammatical; (3) BP allows 3rd person strong pronouns to appear in object position; (4) BP uses null-object constructions, strong pronouns or NPs more often than 3rd person accusative clitics in a greater variety of contexts. Given characteristics number (3) and (4), this study focuses its attention in the acquisition of 1st and 2nd person clitics.

\section{The Present Study}

\subsection{Research Questions and Hypotheses}

Considering what has been discussed so far, the present study intends to examine the source of morphosyntactic transfer in L3 acquisition and what factors determine the occurrence (or not) of this phenomenon, in both production and on-line comprehension measures. More specifically, the research questions this study aims at answering are:

1. Which of the models of L3 transfer previously described better accounts for L3 BP object clitics acquisition in both production and comprehension ways?

2. Are there differences in the extension of the transfer effects for production and comprehension in L3 acquisition?

I conducted two experiments in order to answer these questions. Both experiments were designed in a way that accounted for the predictions of the three models investigated in this study. Based on the discussion in the previous sections, the following hypotheses were considered:

Hypothesis 1. If CEM best describes the data, then transfer could be obtained by both languages, independent of order of acquisition, provided that transfer facilitates (enhances) acquisition of L3 BP object clitics. No negative transfer should be observed. Considering this study's language groupings, however, transfer would be obtained from Spanish, irrespective of its status as an L1 or an L2. This is due to the fact that Spanish, but not English, has object clitics and knowledge of these structures in a previously known language could enhance acquisition of them in the L3, according to this model. It is important to reinforce, nonetheless, that only facilitative (positive) transfer from Spanish should be observed in order for this model to account for the data. No difference between the two learners' groups should be found.

Hypothesis 2. If L2 status factor best describes the data, then no effects from the L1 should be observed in the L3 BP. That is, L1 English speakers would show evidence of influence from Spanish in their L3, whereas L1 Spanish speakers would show evidence of influence from English in their L3. The L1 English group, then, is expected to produce more instances of clitics, clitic climbing and to limit the contexts in which they produce null objects to inanimate and non-specific contexts. Conversely, the L1 Spanish group is expected to produce fewer instances of clitics and to favor, instead, strong pronouns, as well as fewer instances of null objects.

Hypothesis 3. If TPM best describes the data, then transfer is expected to be obtained from either the L1 or the L2, independent of order of acquisition, according to the one that is more (psycho)typologically related to the L3. In this case, Spanish is expected to have a more prominent role in morphosyntactic transfer in the L3 BP. Therefore, it is expected that these learners will produce instances of clitic climbing and few instances of null objects, a construction that would be limited to inanimate and non-specific contexts. Importantly, no differences between the learners' groups is expected (contrary to Hypothesis 2), but, differently from Hypothesis 1, transfer can be observed in both positive and negative ways. 


\subsection{Participants}

There were a total of 33 participants in this study $(N=33)$. They were divided in the following groups:

- Group 1: BP native speakers $(n=9)$

- Group 2: L1 Spanish/L2 English/L3 BP $(n=12)$

- Group 3: L1 English/L2 Spanish/L3 BP $(n=12)$

All participants were enrolled in 1st or 2nd semester Portuguese classes when this study was conducted. They completed a language history questionnaire in order to determine their experiences with the languages under investigation, as well as their self-rated proficiency levels. For the L3 BP groups, only novice and intermediate level learners were included in the study, given that all the models of morphosyntactic transfer assume initial states of acquisition. For the L1 English group, considering that experience with Spanish is relevant, only participants who have been studying Spanish for over three years and self-rated their proficiency as higher than 6 (in a 1 to 10 proficiency scale, in which 1 means not fluent at all and 10 means very fluent) were considered for data analysis. Only BP native speakers who claimed no knowledge of Spanish were included in data analysis, in order to avoid interference from the typologically similar language in the structures that are common between the two of them. Table 1 shows the average self-rated proficiency in BP for the relevant groups. All L3 $\mathrm{BP}$ learners who participated in the study were currently enrolled in American universities and were either native speakers or were very fluent in English.

Table 1. Self-rated proficiency in BP, Spanish and English.

\begin{tabular}{cccc}
\hline Group & BP & Spanish & English \\
\hline BP native speakers $(n=9):$ & & & \\
Mean & 10 & - & - \\
SD & - & - & - \\
L1 Spn $(n=12):$ & & & \\
Mean & 3.58 & 9.58 & 8.83 \\
SD & 0.66 & 0.51 & 0.38 \\
L1 Eng $(n=12):$ & & & \\
Mean & 3.67 & 7.75 & 9.92 \\
SD & 0.65 & 0.75 & 0.28 \\
\hline BP: Brazilian Portuguese; Eng: English; Spn: Spanish; SD: standard deviation.
\end{tabular}

One-way ANOVA comparing the BP self-rated proficiency $(F(2,30)=416, p<0.001)$ was significant between the experimental groups and the native speaker control group $(p<0.001)$, but the experimental groups do not differ from each other $(p=0.72)$. Independent sample $t$-tests between the experimental groups revealed a significant difference in their self-rated proficiency in Spanish $(t(22)=6.95, p>0.001)$ as well as in English $(t(22)=-7.74, p>0.001)$. A paired samples t-test also revealed that, within groups, there is a significant difference in proficiency in their two languages: the L1 Spanish speakers are more proficient in Spanish $(t(11)=3.44, p=0.005)$, whereas the L1 English speakers are more proficient in English $(t(11)=-10.45, p>0.001)$. Consequently, the two experimental groups were comparable on these variables.

Participants completed two experiments. A self-paced reading (SPR) task, which aimed at measuring their online comprehension of object clitics. Then they completed a story-telling task, which measured their performance in oral production. Both experiments were presented on a computer screen, and were completed individually, in a quiet room, after all subjects gave their informed consent for inclusion in the study. The study was conducted after approval by the Ethics Committee of the Florida State University (\#2015.14282). I will describe each experiment, as well as its results, individually in the next sections. 


\subsection{Self-Paced Reading Task}

Participants read 50 items, 16 of which were target sentences with a clitic and 34 were distractors. There were also 16 comprehension questions following the target sentences. The target sentences were divided into four regions, in which Region 2 was the critical one for the purposes of this study, since it contained the clitic. Participants saw a line on the computer screen and had to press a button to be able to read each region. When the button was pressed, the previous region disappeared and participants were able to read the next one, and this process happened successively.

Target sentences were further divided in two conditions, congruent $(n=8)$ and incongruent $(n=8)$ conditions between Spanish and BP, the two languages that have object clitics. The congruent condition consists of proclisis to finite verbs. A negation was added before the clitic, so that proclisis would not only be the preferred position for the clitic in BP, but also the required one by prescriptive rules. That way, enclisis would be considered ungrammatical. An exemplar sentence is seen in (18).

\begin{tabular}{|c|c|c|c|c|c|c|}
\hline 18. a. & $\begin{array}{l}\text { Meu } \\
\text { My }\end{array}$ & $\begin{array}{l}\text { namorado } \\
\text { boyfriend }\end{array}$ & $\begin{array}{l}\text { | não me levou | } \\
\text { not CL1sg took }\end{array}$ & $\begin{array}{l}\text { para um restaurante I } \\
\text { to a restaurant }\end{array}$ & $\begin{array}{l}\text { essa } \\
\text { this }\end{array}$ & $\begin{array}{l}\text { semana. } \\
\text { week }\end{array}$ \\
\hline b. & $\begin{array}{l}{ }^{*} \mathrm{Meu} \\
\mathrm{My}\end{array}$ & $\begin{array}{l}\text { namorado } \\
\text { boyfriend }\end{array}$ & $\begin{array}{l}\text { | não levou-me | } \\
\text { not took-CL1sg }\end{array}$ & $\begin{array}{l}\text { para um restaurante I } \\
\text { to a restaurant }\end{array}$ & essa & $\begin{array}{l}\text { semana. } \\
\text { this week }\end{array}$ \\
\hline
\end{tabular}

The incongruent condition consists of restructuring constructions and the occurrence of clitic climbing. As previously discussed, clitic climbing is not permitted in BP, whereas it is in Spanish. Conversely, BP places the clitic in the middle position, which is ungrammatical in Spanish. An example is provided in (19).

\begin{tabular}{|c|c|c|c|c|c|c|c|c|}
\hline 19. & $\begin{array}{l}\text { Sua } \\
\text { Your }\end{array}$ & $\begin{array}{l}\text { amiga } \\
\text { friend }\end{array}$ & $\begin{array}{l}\text { I vai } \\
\text { is-going }\end{array}$ & $\begin{array}{l}\text { te } \\
\text { CL2sg }\end{array}$ & $\begin{array}{l}\text { mostrar } \\
\text { to-show }\end{array}$ & $\begin{array}{l}\text { | a universidade | } \\
\text { the university }\end{array}$ & $\begin{array}{l}\text { mais } \\
\text { more }\end{array}$ & $\begin{array}{l}\text { tarde. } \\
\text { late }\end{array}$ \\
\hline b. & $\begin{array}{l}\text { *Sua } \\
\text { Your } \\
\text { ‘Your }\end{array}$ & $\begin{array}{l}\text { amiga } \\
\text { friend }\end{array}$ & $\begin{array}{l}\text { I te } \\
\text { CL2sg }\end{array}$ & $\begin{array}{l}\text { vai } \\
\text { is-going }\end{array}$ & $\begin{array}{l}\text { mostrar } \\
\text { to-show }\end{array}$ & $\begin{array}{l}\text { I a universidade I } \\
\text { the university }\end{array}$ & $\begin{array}{l}\text { mais } \\
\text { more }\end{array}$ & $\begin{array}{l}\text { tarde. } \\
\text { late }\end{array}$ \\
\hline
\end{tabular}

Two lists were created and assigned randomly to the participants so that they would never see both the grammatical and the ungrammatical versions of the same sentence. The number of grammatical and ungrammatical sentences per condition was equally divided. Participants' reaction times (RTs) were recorded and statistically analyzed. RTs were used as a measurement of their online processing. As Jegerski points out [36], longer RTs are indicative of processing difficulties; conversely, faster RTs indicate facilitation in processing. That way, this measure can indicate if the learner had any difficulties in processing a certain structure and, according to the cases described above, it can indicate whether transfer occurred. In the incongruent condition, for example, if learners are aware that clitic climbing is impossible in BP, they will present longer RTs, as they encounter difficulties in processing such a construction. Conversely, if transfer from Spanish is obtained, they will present shorter RTs, as they are not aware that this construction is ungrammatical in BP.

I will present the results per group for each condition. In the graphs below, axis $y$ corresponds to RT in milliseconds (ms), and axis $x$ corresponds to each of the regions in the target sentences. Only RTs from Regions 2 and on are presented given they are the ones of relevance to the present study. Data from inaccurate trials in the distractor questions were excluded from data analysis. Figures 1-6 represent the RTs per region in the congruent condition between Spanish and Portuguese, that is, proclisis. 


\section{0}

2100

1900

1700

1500

1300

1100

900

700

Meu namorado $\begin{array}{rr}\text { não me levou para um restaurante essa semana } \\ - \text { Grammatical }\end{array}$

Figure 1. L1 Brazilian Portuguese (BP) speakers in the proclisis condition.

For the native speakers group, paired sample t-tests revealed a significant difference in RTs in the critical Region 2 between the grammatical $(M=1500, S D=715)$ and the ungrammatical $(M=1447$, $\mathrm{SD}=573$ ) sentences; $t(8)=-0.43, p=0.003$. The results are unexpected, since the native speakers seem to be faster at processing the ungrammatical condition. Caution must be taken when analyzing these results because, although enclisis is the dispreferred position for clitics in BP, and the preverbal negation should force proclisis to occur according to prescriptive rules, post-verbal clitics are still a possibility in this language. I will elaborate on that in further details in the discussion section.

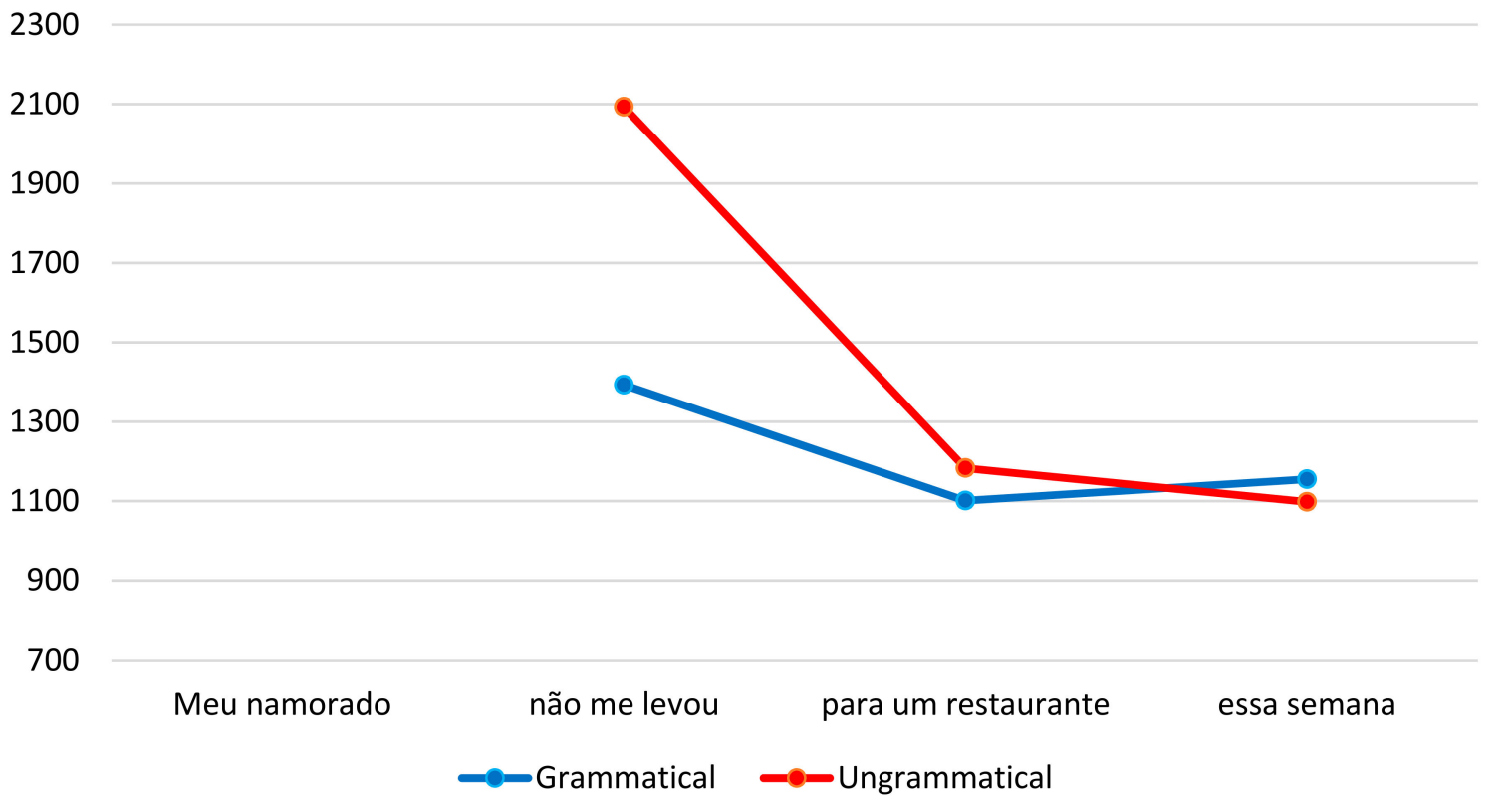

Figure 2. L1 Spanish speakers in the proclisis condition.

For the L1 Spanish group, paired sample t-tests did not reveal significant differences in RTs in the critical Region 2 between the grammatical $(M=1393, S D=625)$ and the ungrammatical $(M=2093$, 
$\mathrm{SD}=1093$ ) sentences; $t(11)=2.2, p=3.8$. That means that participants are performing statistically similarly in both conditions and do not differentiate between them.

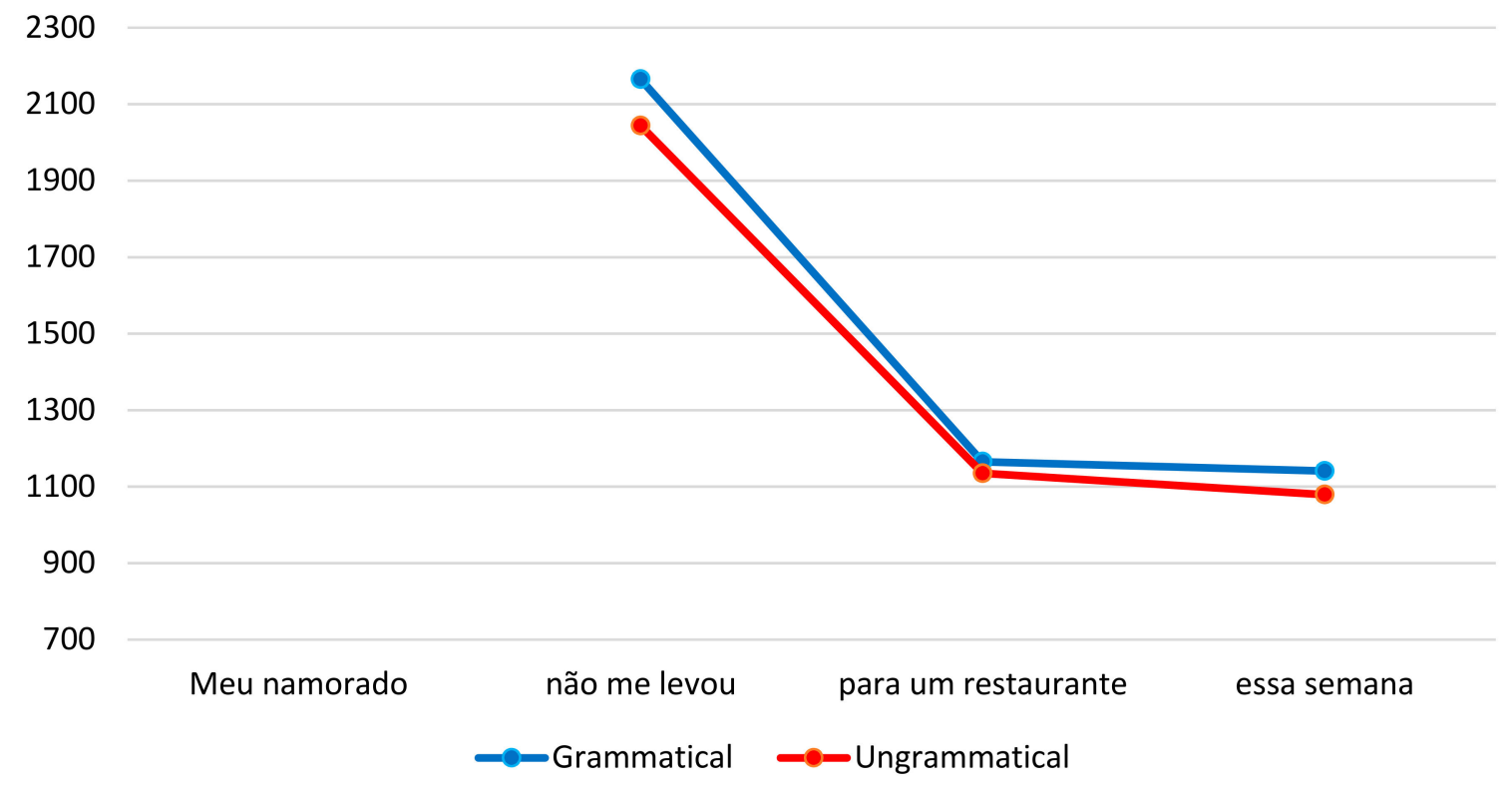

Figure 3. L1 English speakers in the proclisis condition.

For the L1 English group, paired sample t-tests revealed no significant difference in RTs in the critical Region 2 between the grammatical $(M=2165, S D=633)$ and the ungrammatical $(M=2165$, $\mathrm{SD}=620)$ sentences; $t(11)=-0.69, p=0.075$. Similar to the L1 Spanish group, the L1 English group did not present a difference in the processing of the grammatical and ungrammatical conditions.

In sum, this condition did not seem to reveal any evidence of transfer from Spanish. The congruent condition did not facilitate processing of clitic structures by the L3 groups. Nonetheless, it was not detrimental either. It is important to keep in mind the unexpected performance of the BP native speakers group, which was faster at processing the ungrammatical condition. The possible explanations for this observation are raised in the discussion section. I claim this could be a case of overgeneralization of a prescriptive rule for written mode.

Next, I present the results in the incongruent condition, the restructuring constructions. It is important to keep in mind that, in BP, the clitic in the middle position is grammatical, while clitic climbing is ungrammatical.

For the native speaker group, paired sample t-tests revealed a significant difference in RTs in the critical Region 2 between the grammatical $(M=1494, S D=916)$ and the ungrammatical $(M=1155$, $\mathrm{SD}=425$ ) sentences; $t(6)=1.6, p=0.005$, as seen in Figure 4 . This means that the native speakers took longer to process the sentences containing clitic climbing, the ungrammatical position for clitics in $\mathrm{BP}$, than they did to process the ones which had the clitic in the middle position.

For the L1 Spanish group, paired sample t-tests revealed a significant difference in RTs in the critical Region 2 between the grammatical $(M=1229, S D=759)$ and the ungrammatical $(M=1369$, $\mathrm{SD}=834$ ) sentences; $t(11)=1.6, p>0.001$, shown in Figure 5. This suggests the L1 Spanish group is performing native-like in this condition, rejecting clitic climbing, a construction possible in Spanish, and preferring the sentences with the clitic in the middle position, which is ungrammatical in Spanish, but the only possibility for the clitic in BP. 
1700

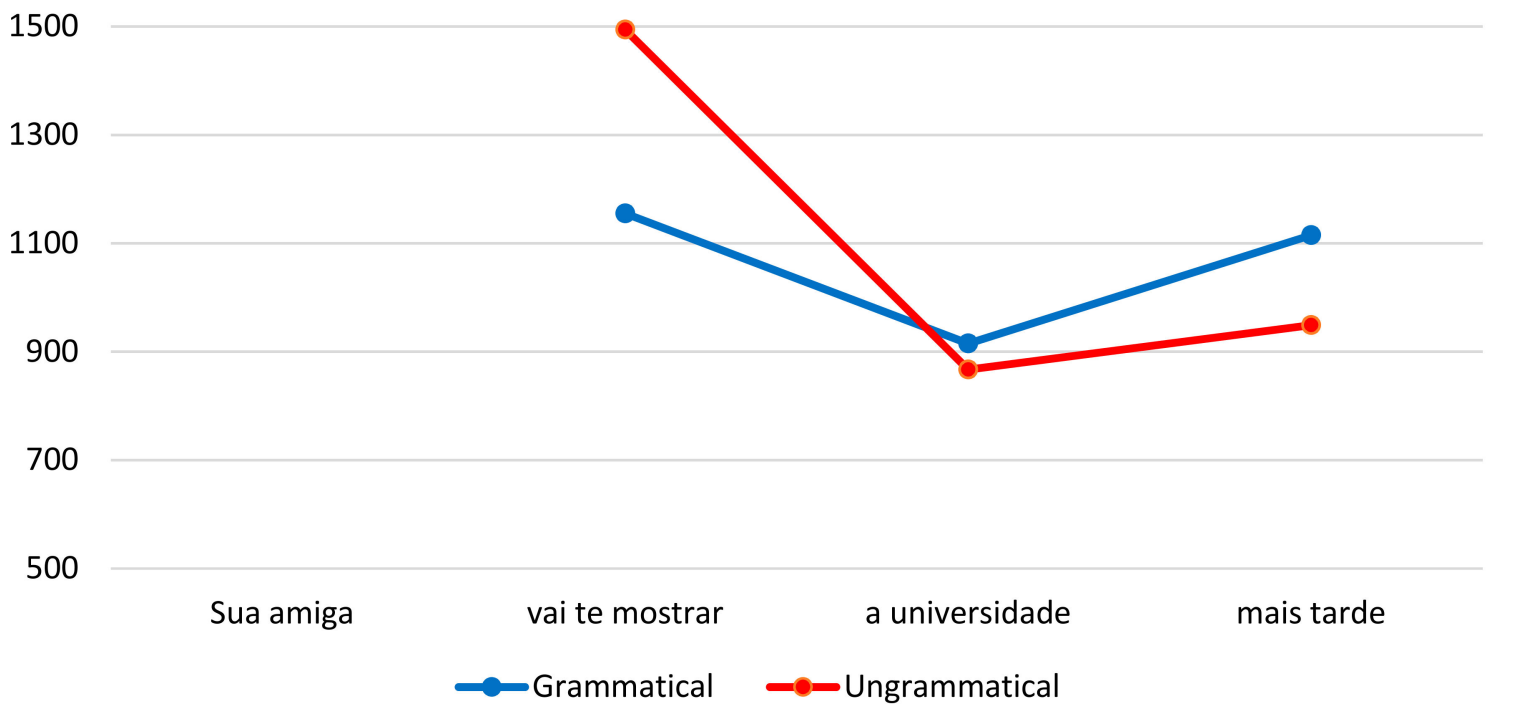

Figure 4. L1 BP speakers in the restructuring condition.

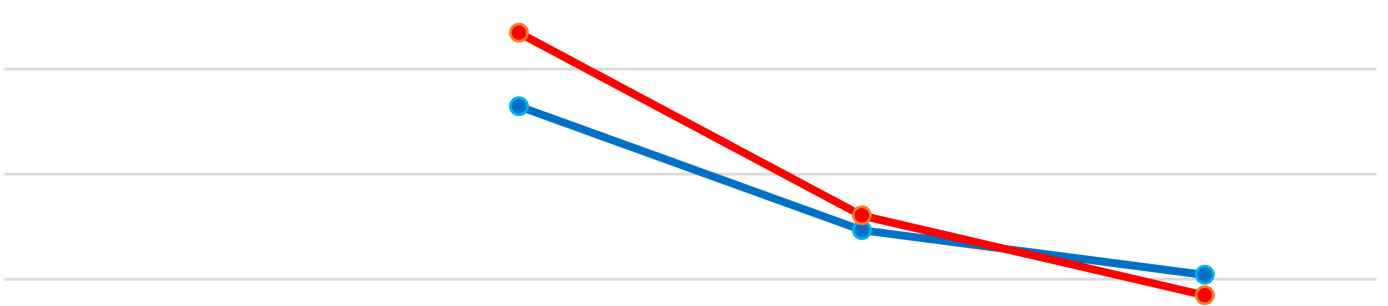

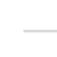


stage, one in which they do not perform target-like, but do not present evidence of transfer from one of their previously known languages either.

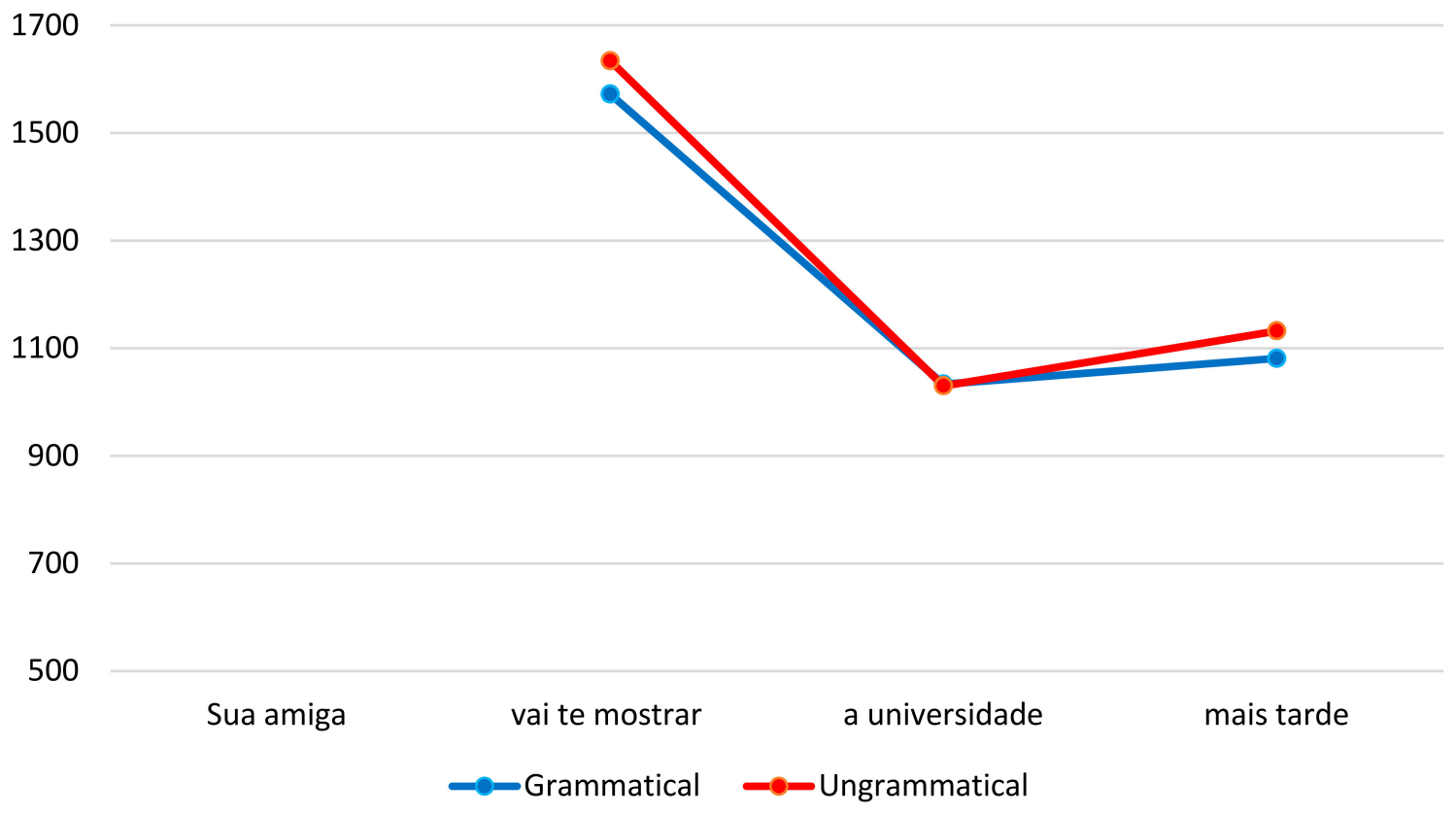

Figure 6. L1 English speakers in the restructuring condition.

\subsection{Story-Telling Task}

The second task aimed at examining the production of clitics by L3 BP learners in their oral speech. That way, it is possible to analyze what constitutes their mental representation when it comes to clitics. Issues on object expression, clitic placement and frequency of use were considered in the analysis of this data.

In this semi-spontaneous production task, participants had to narrate the children's story Little Red Riding Hood (Chapeuzinho Vermelho), based on 12 images presented to them on a computer screen. This task is based on Montrul et al.'s production task [12], but with a slight modification: subjects were told to tell the story using the first person, from the perspective of Little Red Riding Hood, as if they were that character.

As the reader may recall, 3rd person accusative clitics have been disappearing from the BP grammar and, as a result, have become less frequent in the input to which these learners are exposed, even when they learn the standard variety. By having the participants include themselves as a character in the story, I expected to have more instances of 1st and 2nd person clitics, but to also be able to observe occurrences of 3rd person clitics (if used at all) when they refer to the other characters in the story. The goal was twofold: to have them produce forms that they are more likely to have been exposed to via input and, as a result, have them internalized in the linguistic system they are building (and not the forms they are just exposed to through explicit teaching); and to obtain more instances of clitics in the data, targeting one of the limitations identified by Montrul et al. in their experimental design [12].

Participants' speech samples were recorded using a voice recorder. Every recording was transcribed and verified by the investigator, a native speaker of BP. The investigator then coded and analyzed the transcript. For each participant, the type of object used was analyzed under the following categories: clitics (1st and 2nd persons), NPs, strong pronouns, null objects and 3rd person accusative clitics. Reflexive verbs were not included in data analysis, since they present different properties from object clitics. NPs were also excluded from the analysis when they were first introduced in the speech, or when clarification of the referent was necessary, as in a change of referent. This exclusion was necessary so 
that the data analyzed consisted exclusively of clitics or object expressions that were in complementary distribution with clitics, that is, participants could have used a clitic in that position, but, instead, preferred to use a different type of object. Repetitions and reformulations were also excluded from data analysis.

Following [12], a percentage production was calculated for each type of object for each participant who produced those forms. These percentage data were analyzed using ANOVAS ( $F$ statistics). Table 2 shows the number of participants per group who produced each of these forms $(\mathrm{Ns})$, as well as the mean percentages and standard deviations for each of them.

Table 2. Mean percentage distribution (M) of type of object per group.

\begin{tabular}{cccccc}
\hline Group & Clitic & NP & Pronoun & Null & 3rd P. Clitic \\
\hline L1 BP: & & & & & \\
N & 9 & 9 & 5 & 5 & 3 \\
M & $35.8 \%$ & $41.4 \%$ & $11.7 \%$ & $20.4 \%$ & $9.9 \%$ \\
SD & $(17.2)$ & $(19.8)$ & $(8.1)$ & $(9.1)$ & $(4.9)$ \\
L1Spn: & & & & & \\
N & 11 & 11 & 8 & 5 & 1 \\
M & $45.6 \%$ & $32.8 \%$ & $25.1 \%$ & $15.9 \%$ & $7.6 \%$ \\
SD & $(19.1)$ & $(16.7)$ & $(9)$ & $(10.5)$ & - \\
L1Eng: & & & & & \\
N & 10 & 11 & 8 & 3 & 1 \\
M & $44.8 \%$ & $43.4 \%$ & $25.8 \%$ & $14.4 \%$ & $16.6 \%$ \\
SD & $(23.6)$ & $(11)$ & $(13.6)$ & $(9.1)$ & - \\
\hline
\end{tabular}

$\mathrm{N}$ : number of subjects who produced the given structure; M: mean percentage distribution of type of object; NP: Noun Phrase

There were no significant differences among the three groups for any of the variables $(p>0.05)$. That means that all the groups produced comparable rates of clitics, NPs, strong pronouns, null objects and 3rd person accusative clitics. It is also noticeable that few people in every group produced few instances of 3rd person accusative clitics (L1BP $N=3$, L1Spn $N=1$, L1Eng $N=1$, where Spn: Spanish; Eng: English). Instead, there is a preference for the forms in direct complimentary distribution with them, such as NPs, strong pronouns and null objects. It is also interesting to note how these learners are aware of the possibility of using null object construction in BP, a construction not very present in neither of their previously known languages. Finally, no occurrences of the 3rd person accusative clitic lo/la from Spanish was obtained in their speech samples.

Although the mean percentage distribution of types of objects show a correspondence in terms of object expression between the grammar of native speakers and the grammar of these learners, evidence of clitic misplacement in the L3 BP learners' speech samples was found. BP native speakers exclusively used proclisis with both finite and non-finite verbs. L3 BP learners, although also exclusively used proclisis with finite verbs, placed the clitic post-verbally with non-finite verbs in every occurrence of such construction, as exemplified in (20). Remember that, although this form is not completely unacceptable in BP, it is the least common, as shown by the fact that no native speaker used it, and indicates some transfer from Spanish, in which such position would be the only one available for the clitic.

20. ?... para comer-me.

to eat-CL1sg

Also, while in restructuring constructions BP native speakers exclusively placed the clitic in the middle position, L3 BP learners used all three possible positions, with a preference for clitic climbing (21a) and non-climbing (21b), both available positions for the clitic in Spanish, but not in BP. 


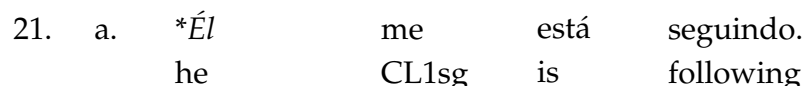

'He is following me'

b. ?.... tentou pegar-me.

tried to-catch-CL1sg

'tried to catch me'

Also, all the groups used 3rd person accusative clitics, but there was a different pattern. The native speakers solely used 3rd person clitics to refer to an animate and specific referent, the grandmother in the children's story (22a). L3 learners, on the other hand, used this same form to refer to an animate and specific referent, the grandmother $(22 b)$, as well as an inanimate and non-specific referent, the word rocks (22c).

22. a.

$\begin{array}{ll}\text {... o } & \text { lobo malvado } \\ \text { the } & \text { wolf bad }\end{array}$

'the bad wolf swallowed her'

b. ... porque o lobo a

because the wolf

CL3sg

CL3sg

engoliu.

L1 BP

'because the wolf ate her'

c. … pegamos pedras e as pusimos dentro da sua barriga.
we-collected rocks and CL3pl put inside of his
'We collected rocks and we put them inside of his stomach'

As the examples above indicate, there seems to be a tendency in which the native speakers exclusively use 3rd person accusative clitics to refer to animate and specific referents, whereas the use of these forms seems to be more unrestricted for the L3 groups. Nevertheless, since each experiment group used these clitics only once in their speech, we cannot assume they are following a specific pattern. More data would be necessary in order to make further claims.

Finally, the contexts in which null objects are used also seems to differ between the native speakers group and the two experiment groups. The native speakers produced instances of null objects in a relatively unconstrained set of contexts, including animate and specific (23a), inanimate and specific (23b) and inanimate and non-specific (23c) contexts. Both L3 groups, on the other hand, used null object constructions exclusively in inanimate and non-specific contexts (24).

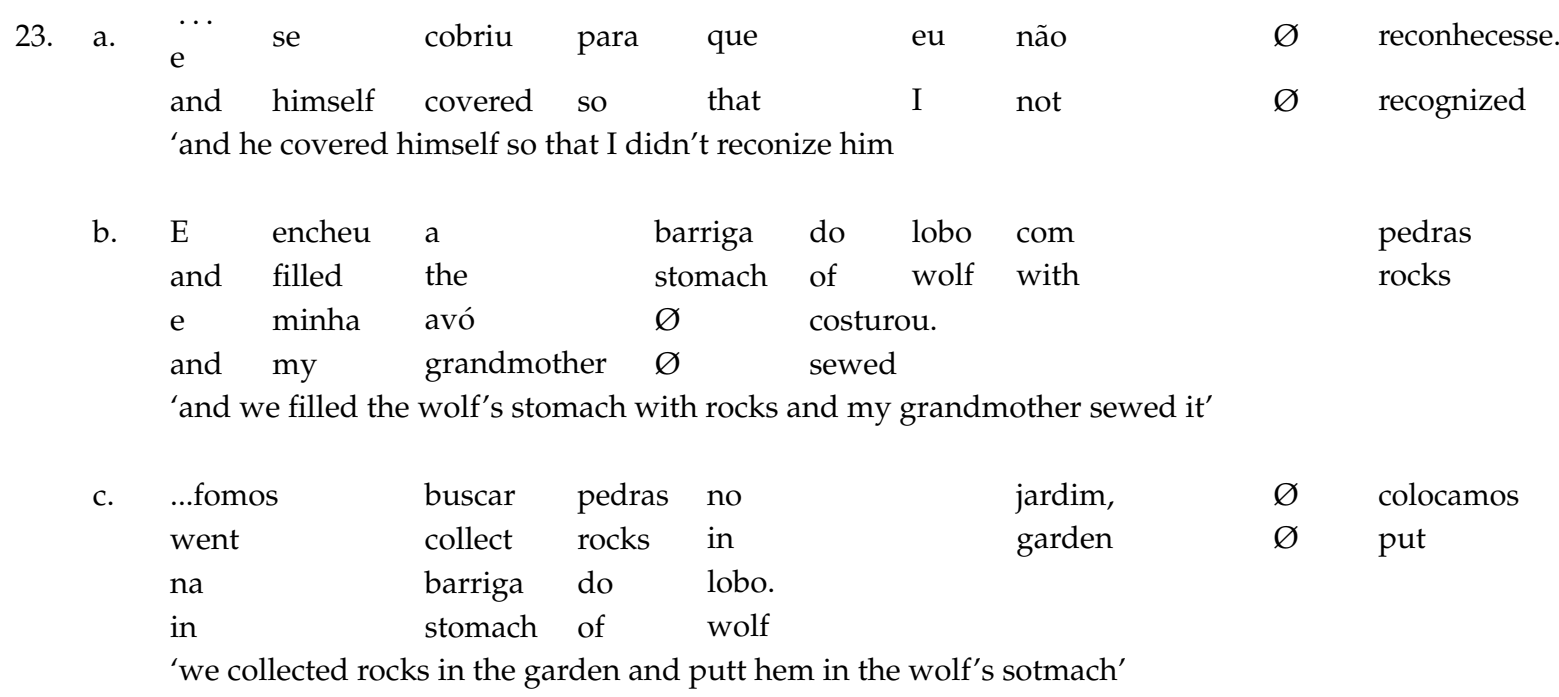


24. ...eu trouxe pedras de fora para colocar $\varnothing$ na barriga do lobo.

I brought rocks from outside to put $\varnothing$ in stomach of wolf

'I brought rocks from outside to put them in the wolf's stomach'

This indicates that, although these learners are aware that BP allows null objects to occur, they still limit the use of this construction to contexts in which it is allowed in one of their previously known languages, namely, Spanish. In other words, there seems to be evidence of transfer from Spanish to their L3 in what refers to the use of null object constructions, irrespective of order of acquisition or status as an L1 or an L2.

Given the low number of occurrences of clitics in the participants' speech, as well as the inconsistency in the frequency of clitic production in each of the conditions mentioned above, these errors are not statistically significant. A much larger sample of participants would be needed in order for a better analysis of these phenomena. However, when paired with Montrul et al.'s results [12], it is possible to perceive a tendency in L3 BP learners to follow the syntax of Spanish, mainly in constructions that involve non-finite verbs and clitic climbing.

In sum, there was no significant difference on the rates of any type of object among the three groups. This suggests an early convergence between the grammar of the L3 learners and the native speakers, which could indicate that clitics are structures rather easily acquired, as well as the different possibilities of object expression in BP. That could also indicate some sort of facilitative influence from Spanish, a language that shares these structures with BP, and posterior reset of features referent to the possibilities of replacement of the 3rd person accusative clitics can be obtained. There is only evidence of negative influence from Spanish when we pay closer attention to clitic placement and the use of null object constructions. Although not statistically significant, the data obtained in this study provides further support to the findings by Montrul et al. in what refers to clitic placement errors [12].

\section{Discussion}

The present study addressed the role of L1 and L2 in L3 acquisition. In particular, I investigated the proposed models of language transfer in L3 acquisition and their predictions. Such a goal was achieved by the investigation of a syntactic structure, object clitics, which is common to two of the languages considered for the study, BP and Spanish, but it is not present in English. There were two groups of learners, in addition to a control group. I had mirror image groups in relation to their L1 and L2, while maintaining the L3 constant. The two experiments focused on object clitic expression in L3 BP by means of an on-line comprehension task, as well as a semi-spontaneous oral production task. Given the diachronic changes of BP grammar discussed in Section 3, I focused on 1st and 2nd person object clitics. Three hypotheses were investigated, based on the assumptions of three different models of morphosyntactic transfer in L3 acquisition: the CEM [7], the L2 status factor [8], and the TPM [6].

The SPR task did not indicate major effects of language transfer for any of the groups investigated. On the congruent condition, proclisis, the native speaker group performed unexpectedly, presenting faster RTs in the ungrammatical condition. Although enclisis is still available in BP, it is the least common position for the clitic, and, as the reader may recall, under prescriptive rules, a clitic must be placed pre-verbally when in the presence of a negation such as in the sentences for this condition. The results obtained could be explained by the language mode, which may have influenced the results: enclisis persists in formal BP, more specifically in the written mode. Since participants read the sentences, they could have identified this task as targeting formal language and, therefore, showed preference towards enclitic constructions. An anonymous reviewer, however, pointed out that enclisis is not allowed in the presence of a negation in any variety, not even in EP, a variety in which the post-verbal position for the clitic is still very productive. I agree with this comment, but it seems that this is a case of overgeneralization of a rule. As mentioned in the prior discussion, oral grammar uses proclisis exclusively. The written register, on the other hand, favors enclisis and has proclisis as an exception for a few contexts, represented in (2-3). Although the presence of a negation word should have forced the use of a pre-verbal clitic, the native speakers followed the rule of using enclisis in the written register. 
As a result, they generalized the clitic placement prescriptive rules in written mode as "always use enclisis" and hypercorrected themselves. This explains why they are the only group to favor enclisis in this condition. Future studies using a self-paced listening task, for example, could corroborate this claim. More importantly, to the matter of this study, neither L3 groups performed target-like. Under this condition, similarity to Spanish was not facilitative, and transfer was not obtained.

In the incongruent condition, the restructuring sentences, the L1 Spanish group performed similarly to the control group and was faster at accepting the sentences in which the clitic was placed in the middle position than the ones with clitic climbing. The L1 English group, however, did not present a significant difference in their RTs to the grammatical and ungrammatical sentences in this condition. This suggests a slight advantage for the L1 Spanish group, which can be explained by the fact that Spanish, their L1, also has clitics in its grammar, and processing of these structures may be enhanced, facilitating the reset of such parameter in the L3. As a result, there is no negative transfer from their L1 into their L3. Nonetheless, there was no observable transfer in the L1 English group either, since this group did not demonstrate preference for the sentences containing clitic climbing. It seems that this group, although in a slower pace than the other L3 group, is in the process of adjusting its L3 mental representation in accordance to the BP native grammar.

The production task revealed that the L3 learners converge in the grammar of native BP speakers in what refers to object expression. There seems to be evidence that these learners have also acquired the null object constructions, as well as the use of NPs and strong pronouns in detriment of the 3rd person accusative clitics. Given that clitics are also present in one of their previously known languages, this early convergence to the native grammar in their L3 interlanguage development may be explained in terms of positive transfer from Spanish. It could also suggest that these structures are rather easy to be acquired and do not probe much difficulty to language learners.

Although not statistically significant, the oral production task seems to indicate transfer effects from Spanish in what refers to clitic placement and the occurrence of null object constructions. Participants produced target-like sentences in the condition of finite verbs, placing the clitic pre-verbally, the preferred position for the clitic in BP and the only possibility in Spanish. Nonetheless, participants made placement errors in conditions not shared by BP and Spanish, and placed clitics post-verbally in non-finite contexts. Also, in restructuring conditions, they used clitic climbing, which is totally unacceptable in BP, and non-climbing, which is just somewhat acceptable in BP but not present in the native speakers' data. Participants also used null object constructions in more limited contexts than native speakers. Both L3 groups used null object constructions exclusively in inanimate and non-specific contexts, the only case in which this construction would be acceptable in Spanish. The native speakers, on the other hand, used this construction in a wider range of contexts, which shows that null objects are acceptable to them in a relatively unconstrained manner. These placement errors and preference in some contexts for null object constructions can be traced back to Spanish and these results are in accordance to what Montrul et al. found in their study [12].

VanPatten says that language acquisition unfolds in the following manner: first, learners need to correctly process the structure being acquired, making the appropriate form-meaning connections; then, parameterization and the relevant syntactic operations take place, in order to build a mental representation of the language they are acquiring [37]. The results of this investigation indicate these learners are able to process object clitics in BP for their meaning and function in the sentence, as observed by the SPR task. However, results from the production task indicate they are still in the process of (re)setting the parameters relevant to these structures, in order to obtain the native-like placement of them.

I return now to my first research question and the hypotheses raised at the beginning of Section 4 . I investigated which of the models of L3 transfer, namely the CEM, the L2 status factor, and the TPM, best describes L3 BP object clitics acquisition for both production and comprehension. Hypothesis 1 was based on the claims by the CEM and predicted that either the L1 or the L2 could be the source of transfer, provided that this transfer was facilitative in manner. Although it can be argued that 
knowledge of clitics enhanced acquisition of these forms in the L3, especially in terms of their production, some negative transfer was observed with regards to clitic placement in the production task. Therefore, this hypothesis is refuted.

Hypothesis 2 followed the L2 status factor constructs and predicted the L2 as the only source of transfer. Transfer, when observed, seems to have come exclusively from Spanish, independent of order of acquisition. As a result, hypothesis 2 is also refuted. Hypothesis 3, in accordance to the TPM, predicted that transfer would be obtained from the most typologically similar language to the L3, in this case, Spanish, and that it could be either facilitative or negative. Given that previous knowledge of clitic structures can be argued to have enhanced the acquisition of these forms, as well as that the placement errors and the contexts in which the L3 groups used null objects found in the data can be traced back exclusively to Spanish, hypothesis 3 is partially sustained and the TPM seems to better account for the data.

It must be said, however, that the participants in this study seem to have acquired the appropriate features of L3 BP object clitics and the effects of transfer are minimal. If there is, as the TPM claims, a stage of full transfer from the typologically similar language, such period may be surpassed quite early in the acquisition process. As the data suggests, these learners, even at initial states of acquisition, already present evidence of convergence to the native grammar and some residues of non-target-like constructions were observed.

The second research question investigated whether there are differences in the extension of the transfer effects in comprehension and production in L3 acquisition. The results suggest there was no transfer in the comprehension task, but some minor effects of transfer were observed in the production task. Consider the language acquisition process as described by VanPatten and Cadierno [38], reproduced below.

Comprehension, or, as indicated in Figure 7, processing of linguistic structures, is one of the initial steps in language acquisition. It is reasonable to claim, thus, that the effects of transfer may be overridden in comprehension earlier than in production, which represents the last of the steps in the schema above. As VanPatten says, language acquisition initiates by appropriate processing of language structures, then parameterization begins [37]. It is not that production is more susceptible to transfer than comprehension, but the effects of transfer can be observed for a longer period of time in the former since it is the last process of language acquisition.

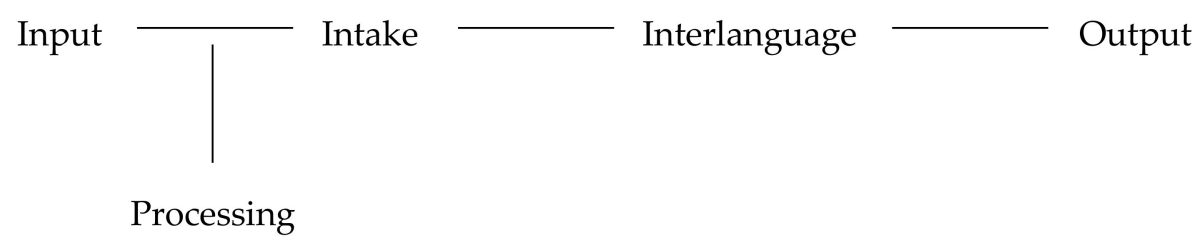

Figure 7. Process of language acquisition [38].

The models of morphosyntactic transfer investigated in this study focus on the initial states of language acquisition and claim wholesale transfer. It seems, however, that, if such period does exist, it is overcome quite early in the acquisition process. Future research should address this developmental issue in order to determine when the effects of transfer are no longer observed. Also, future studies should investigate the effects of language transfer beyond the initial states and address the claims of recently proposed models, such as the linguistic proximity model [39] and the scalpel model [40]. Furthermore, the results of the present investigation need to be corroborated by studies with a larger poll of participants, in order to find stronger empirical support for its claims. The difficulty in conducting studies in L3 acquisition is related to the language pairings and the availability of participants that fit the requirements of the investigation. This is a hindrance that researchers in L3 acquisition have faced since the emergence of the field and that we all hope becomes less and less challenging with the growth of the multilingual population. 


\section{Conclusions}

In this paper, I have investigated the role that L1 and L2 play in L3 interlanguage development in both production and comprehension measures, based on the claims made by three different models for L3 transfer. Results indicate that comprehension can overcome the effects of transfer earlier than production. Furthermore, the production data indicates that TPM is the model that can better describe the transfer phenomenon in L3 BP acquisition. It is important to say, as pointed out by Rothman [6], that typology may not be as relevant for certain language groupings as it was for the one investigated in this study. According to the author, the TPM does not preclude the L2 status factor from being operative in general; his claim is that, in the case both models are in direct competition, typological proximity will be the most deterministic factor in multilingual transfer. Future research must consider different language pairings in order to expand our knowledge about such phenomena.

Acknowledgments: I would like to thank Silvina Montrul, who kindly shared her oral production materials with me. I also would like to thank Michael Leeser for his assistance in the conduction of this study, and Mackenzie Teek, who assisted me with data collection. I also thank the three anonymous reviewers for their helpful criticism of this work. All remaining errors are my own.

Conflicts of Interest: The author declares no conflict of interest.

\section{References}

1. Jaensch, C. Third language acquisition: Where are we now? Linguist. Approaches Biling. 2003, 3, 73-93. [CrossRef]

2. Jordà, M.P.S. Third Language Learners: Pragmatic Production and Awareness; Multilingual Matters: Clevedon, UK, 2005.

3. Cenoz, J. The additive effect of bilingualism on third language acquisition: A review. Int. J. Biling. 2003, 7, 71-87. [CrossRef]

4. Cenoz, J.; Hufeisen, B.; Jessner, U. Cross-Linguistic Influence in Third Language Acquisition: Psycholinguistic Perspectives; Multilingual Matters: Clevedon, UK, 2001.

5. Herdina, P.; Jessner, U. A Dynamic Model of Multilingualism. Perspectives of Change in Psycholinguistics; Multilingual Matters: Clevedon, UK, 2002.

6. Rothman, J. L3 syntactic transfer selectivity and typological determinacy: The typological primacy model. Second Lang. Res. 2011, 27, 107-127. [CrossRef]

7. Flynn, S.; Foley, C.; Vinnitskaya, I. The cumulative-enhancement model for language acquisition: Comparing adults' and children's patterns of development in first, second and third language acquisition of relative clauses. Int. J. Multiling. 2004, 1, 3-16. [CrossRef]

8. Bardel, C.; Falk, Y. The role of the second language in third language acquisition: The case of Germanic syntax. Second Lang. Res. 2007, 23, 459-484. [CrossRef]

9. Berkes, É.; Flynn, S. Further evidence in support of the Cumulative-Enhancement Model: CP structure development. In Third Language Acquisition in Adulthood; Amaro, J.C., Flynn, S., Rothman, J., Eds.; John Benjamins: Amsterdam, The Netherlands, 2012; pp. 143-164.

10. Falk, Y.; Bardel, C. Object pronouns in German L3 syntax: Evidence for the 2 status factor. Second Lang. Res. 2011, 27, 59-82. [CrossRef]

11. Rothman, J.; Amaro, J.C. What variables condition syntactic transfer? A look at the L3 initial state. Second Lang. Res. 2010, 26, 189-218. [CrossRef]

12. Montrul, S.; Dias, R.; Santos, H. Clitics and object expression in the L3 acquisition of Brazilian Portuguese: Structural similarity matters for transfer. Second Lang. Res. 2011, 27, 21-58. [CrossRef]

13. Flynn, S. A Study of the Effects of Principal Branching Direction in Second Language Acquisition: The Generalization of a Parameter of Universal Grammar from First to Second Language Acquisition. Ph.D. Thesis, Cornell University, Ithaca, NY, USA, 1983.

14. Flynn, S. A Parameter-Setting Model of L2 Acquisition: Experimental Studies in Anaphora; Reidel: Dordrecht, The Netherlands, 1987. 
15. Bardel, C.; Falk, Y. Behind the L2 status factor: A neurolinguistic framework for L3 research. In Third Language Acquisition in Adulthood; Amaro, J.C., Flynn, S., Rothman, J., Eds.; John Benjamins: Amsterdam, The Netherlands, 2012; pp. 61-78.

16. Paradis, M. Language and communication disorders in multilinguals. In Handbook of the Neuroscience of Language; Stemmer, B., Whitaker, H.A., Eds.; Elsevier: Amsterdam, The Netherlands, 2008; pp. 341-349.

17. Rothman, J. Linguistic and cognitive motivations for the typological primacy model of third language (L3) transfer: Timing of acquisition and proficiency considered. Biling. Lang. Cogn. 2015, 18, 179-190. [CrossRef]

18. Schwartz, B.; Sprouse, R. Word order and nominative case in nonnative language acquisition: A longitudinal study of (L1 Turkish) German interlanguage. In Language Acquisition Studies in Generative Grammar: Papers in Honor of Kenneth Wexler from the 1991 GLOW Workshops; Hoekstra, T., Schwartz, B., Eds.; John Benjamins: Amsterdam, The Netherlands, 1994; pp. 317-368.

19. Schwartz, B.; Sprouse, R. L2 cognitive states and the full transfer/Full access modal. Second Lang. Res. 1996, 12, 40-72. [CrossRef]

20. Kellerman, E. Transfer and no transfer: Where we are now. Stud. Second Lang. Acquis. 1979, 2, 37-57. [CrossRef]

21. Kellerman, E. Now you see it, now you don't. In Language Transfer in Language Learning; Gass, S.M., Selinker, L., Eds.; Newbury House: Rowley, MA, USA, 1983; pp. 112-134.

22. Soriano, O.M.F. El pronombre personal. Formas y distribuciones. Pronombres átonos y tónicos. In Gramática Descriptiva de la Lengua Española; Demonte, V., Bosque, I., Eds.; Espasa Calpe: Madrid, Spain, 1999; pp. 1209-1274.

23. Galves, C.; Ribeiro, I.; Moraes, M.A.T. Syntax and morphology in the placement of clitics in European and Brazilian Portuguese. J. Port. Linguist. 2005, 42, 143-177. [CrossRef]

24. Galves, C. Agreement, prediction, and pronouns in the history of Portuguese. In Portuguese Syntax: New Comparative Studies; Costa, J., Ed.; Oxford University Press: New York, NY, USA, 2000; pp. 143-168.

25. Cyrino, S.M.L. Algumas questões sobre a elipse de VP e objeto nulo em PB e PE. In Teoria e Análise Lingüísticas: Novas Trilhas; Guedes, M., de Andrade Berlinck, R., de Almeida Azevedo Murakawa, C., Eds.; Laboratório Editorial FCL/UNESP: Araraquara, Brazil, 2006; pp. 53-79.

26. Cyrino, S. On complex predicates in Brazilian Portuguese. Iber. Int. J. Theor. Linguist. 2011, 2, 1-21.

27. Abaurre, M.B.M.; Galves, C. Os clíticos no português brasileiro: Elementos para uma abordagem sintático-fonológica. In Gramática do Português Falado 4; Castilho, A., Basílio, M., Eds.; Editora da Unicamp: Campinas, Brazil, 1996; pp. 267-312.

28. Nunes, J. Direção de cliticização, objeto nulo e pronome tônico na posição de objeto em Português Brasileiro. In Português Brasileiro: Uma Viagem Diacrônica (Homenagem a Fernando Tarallo); Roberts, I., Kato, M., Eds.; Editora da Unicamp: Campinas, Brazil, 1993; pp. 207-222.

29. Nunes, J. On the diachronic reanalysis of null subjects and null objects in Brazilian Portuguese: Triggers and consequences. In the Development of Grammar: Language Acquisition and Diachronic Change-in Honor of Jürgen M. Meisel; Rinke, E., Kupisch, T., Eds.; John Benjamins: Amsterdam, The Netherlands; Philadelphia, PA, USA, 2011; pp. 331-354.

30. Silveira, G. O Comportamento Sintático dos Clíticos no Português Brasileiro. Master's Thesis, Universidade Federal de Santa Catarina, Florianópolis, Brazil, 1997.

31. Coelho, P. O Alquimista, 56th ed.; Rocco: Rio de Janeiro, Brazil, 1990.

32. Coelho, P. O Alquimista, 11th ed.; Pergaminho: Lisbon, Portugal, 1999.

33. Corrêa, V.R. O Objeto Direto Nulo no Português do Brasil. Master's Thesis, Universidade Estadual de Campinas, Campinas, Brazil, 1991.

34. Kato, M.; Cyrino, S.; Corrêa, V. Brazilian Portuguese and the recovery of lost clitics through schooling. In Minimalist Inquiries into Child and Adult Language Acquisition: Case Studies across Portuguese; Pires, A., Rothman, J., Eds.; Mouton De Gruyter: Belin, Germany; New York, NY, USA, 2009; pp. 245-274.

35. Rizzi, L. Null objects in Italian and the theory of pro. Linguist. Inq. 1986, 17, 501-557.

36. Jegerski, J. Self-paced reading. In Research Methods in Second Language Psycholinguistics; Jegerski, J., Van Patten, B., Eds.; Routledge: Oxford, UK, 2014; pp. 20-49.

37. Van Patten, B. Processing perspectives on instructed second language acquisition. In The Cambridge Handbook of Bilingual Processing; Schwieter, J.W., Ed.; Cambridge University Press: Cambridge, UK, 2015. 
38. Van Patten, B.; Cadierno, T. Input processing and second language acquisition: A role for instruction. Mod. Lang. J. 1993, 77, 45-57. [CrossRef]

39. Mykhaylyk, R.; Mitrofanova, N.; Rodina, Y.; Westergaard, M. The Linguistic Proximity Model: The case of Verb-Second revisited. In BUCLD 39: Proceedings, Proceedings of the 39th Annual Boston University Conference on Language Development, Boston, MA, USA, 7-9 November 2014; Cascadilla Press: Somerville, MA, USA, 2015.

40. Slabakova, R. The scalpel model of third language acquisition. Int. J. Biling. 2016, 1-15. [CrossRef]

(C) 2017 by the author. Licensee MDPI, Basel, Switzerland. This article is an open access article distributed under the terms and conditions of the Creative Commons Attribution (CC BY) license (http:/ / creativecommons.org/licenses/by/4.0/). 